\title{
Research Letter
}

\section{Host Specificity in the Parasitic Plant Cytinus hypocistis}

\author{
C. J. Thorogood and S. J. Hiscock \\ School of Biological Sciences, University of Bristol, Woodland Road, Bristol BS8 1UG, UK \\ Correspondence should be addressed to C. J. Thorogood, chris.thorogood@bristol.ac.uk \\ Received 2 September 2007; Accepted 14 December 2007 \\ Recommended by John J. Wiens
}

Host specificity in the parasitic plant Cytinus hypocistis was quantified at four sites in the Algarve region of Portugal from 2002 to 2007. The parasite was found to be locally host specific, and only two hosts were consistently infected: Halimium halimifolium and Cistus monspeliensis. C. hypocistis did not infect hosts in proportion to their abundance; at three sites, $100 \%$ of parasites occurred on $H$. halimifolium which represented just $42.4 \%$, 3\% and $19.7 \%$ of potential hosts available, respectively. At the remaining site, where $H$. halimifolium was absent, $100 \%$ of parasites occurred on C. monspeliensis which represented $81.1 \%$ of potential hosts available. Other species of potential host were consistently uninfected irrespective of their abundance. Ecological niche divergence of host plants $H$. halimifolium and $C$. monspeliensis may isolate host-specific races of $C$. hypocistis, thereby potentially driving allopatric divergence in this parasitic plant.

Copyright (C) 2007 C. J. Thorogood and S. J. Hiscock. This is an open access article distributed under the Creative Commons Attribution License, which permits unrestricted use, distribution, and reproduction in any medium, provided the original work is properly cited.

\section{INTRODUCTION}

The distribution of a parasite is restricted by its host range [1]. Most parasitic plants can potentially parasitize a diverse range of hosts, and they are thus considered to be generalists $[2,3]$. However, many parasites vary in their host specificity [4], and even generalists show high levels of host preference [5]. Therefore, while many species potentially act as hosts in a population, the majority of those infected comprises a subset of those available [3]. Most studies have considered the range of hosts infected rather than the range of potential hosts in a given population [2], and few studies have extended beyond a one-year period [6]. Host specificity is related to both the abundance and diversity of potential hosts in a population $[3,4,7]$. The most heavily parasitized species are often competitive dominants [3] where host abundance selects for parasite specialization. Conversely, as the diversity of potential hosts in a population increases, the probability of a specialist locating a suitable host decreases, selecting for a generalist strategy [4]. Parasitic plants are keystone species, profoundly affecting plant community structure by altering the competitive balance between host and nonhost species [3]. Despite this, the host range of most parasitic plants is poorly understood and often based on anecdotal sources [1,7].

Species of the holoparasitic angiosperm genus Cytinus (Cytinaceae) grow endophytically, within the tissues of the host plant (see Figure 1). Little is known of the life history or ecology of this genus, but C. hypocistis is known to be parasitic on various members of the Cistaceae, including white-flowered Cistus spp. and Halimium spp. [8]. While C. hypocistis can infect a number of species in these genera, it is unknown whether the parasite is host-specific. The aims of this study were to (1) quantify the degree of host specificity of C. hypocistis on different species of Halimium and Cistus at multiple sites, (2) assess the relative abundance of potential host species at each site, and (3) compare the infection densities at each site, over a period of six years. Our survey shows that C. hypocistis does not use all potential hosts equally, and host abundance does not predict the prevalence of the parasite in the Algarve region of Portugal. This is the first study to quantify the host specificity of this parasite, over a timescale of several years.

\section{MATERIALS AND METHODS}

All study sites were in the southwest of the Algarve region of Southern Portugal: Amoreira (site 1) $\left(37^{\circ} 21.122 \mathrm{~N}\right.$, $008^{\circ} 50.432 \mathrm{~W}$; elevation $21 \mathrm{~m}$ ) and Salema (site 2) $\left(37^{\circ} 07.502 \mathrm{~N}, 008^{\circ} 82.555 \mathrm{~W}\right.$; elevation $\left.47 \mathrm{~m}\right)$ in 2002 , then additionally at the Lagoa Funda (site 3) $\left(37^{\circ} 07.372 \mathrm{~N}\right.$, $008^{\circ} 53.692 \mathrm{~W}$; elevation $136 \mathrm{~m}$ ) in 2004 and 2006 and at 
TABLE 1: Pooled mean percentage values of potential host composition at sites 1-4. Values for hosts infected are expressed as the mean total percentage of infected hosts sampled during years. Values for the number of parasites per host are expressed as the mean number of inflorescences growing under every infected host plant. Values for the range and standard error are included for sites which were sampled in two or more years.

\begin{tabular}{|c|c|c|c|c|c|}
\hline Site & Study years & Potential host species & $\begin{array}{l}\text { Mean \% poten- } \\
\text { tial hosts per } \\
\text { quadrat (range) }\end{array}$ & $\begin{array}{l}\text { Mean } \% \text { hosts } \\
\text { infected per } \\
\text { quadrat } \pm \text { se }\end{array}$ & $\begin{array}{l}\text { Mean parasites } \\
\text { per host (range) }\end{array}$ \\
\hline \multirow{3}{*}{1} & \multirow{3}{*}{ 2002, 2004, 2006, 2007} & H. halimifolium & $42.4(23.2-59.4)$ & $30.8 \pm 13.1$ & $6.4(1.5-12.6)$ \\
\hline & & H. calycinum & $17.1(8.0-29.0)$ & - & - \\
\hline & & C. salvifolius & $40.5(24.3-61.6)$ & - & - \\
\hline \multirow{3}{*}{2} & \multirow{3}{*}{ 2002, 2004, 2006, 2007} & C. monspeliensis & $81.1(50.3-97.0)$ & $13.8 \pm 5.6$ & $1.6(0.9-2.3)$ \\
\hline & & C. albidus & $11.9(2.0-25.7)$ & - & - \\
\hline & & C. ladanifer & $7.0(1.0-15.0)$ & - & - \\
\hline \multirow{4}{*}{3} & \multirow{4}{*}{2004,2006} & H. halimifolium & $3.0(2.0-4.0)$ & $36.7 \pm 31.0$ & $4.16(3.14-5.18)$ \\
\hline & & H. calycinum & $5.5(4.0-7.0)$ & - & - \\
\hline & & C. salvifolius & $3.5(3.0-4.0)$ & - & - \\
\hline & & C. crispus & $88.0(88.0-88.0)$ & - & - \\
\hline \multirow{4}{*}{4} & \multirow{4}{*}{2007} & H. halimifolium & 19.7 & 11.3 & 1.3 \\
\hline & & H. calycinum & 43.4 & - & - \\
\hline & & C. salvifolius & 28.9 & - & - \\
\hline & & C. ladanifer & 7.9 & - & - \\
\hline
\end{tabular}

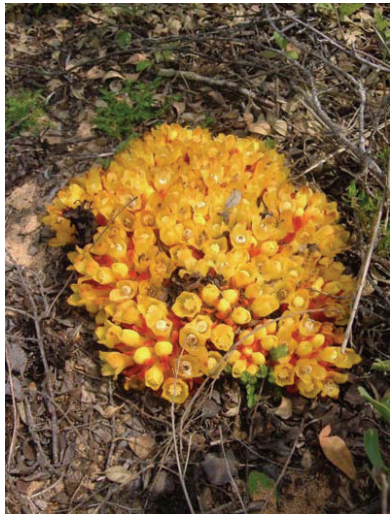

(a)

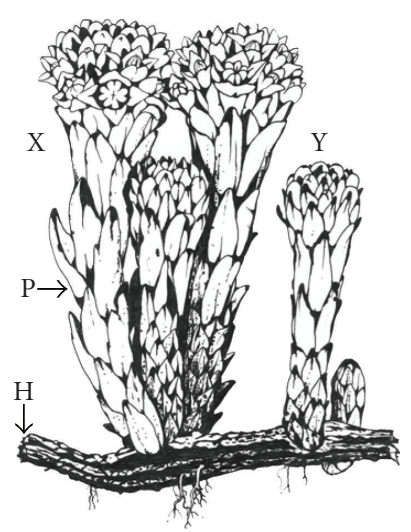

(b)
Figure 1: (a) Growth habit of C. hypocistis growing on H. halimifolium, showing a clump of multiple inflorescences, arising from a single parasite; (b) C. hypocistis ( $\mathrm{P}$ ) growing as an endophytic parasite within the host-root tissues $(\mathrm{H})$. Plants $\mathrm{X}$ and $\mathrm{Y}$ may be individual parasites or may arise from a common systemic infection of the host-root system (diagram is drawn by C. J. Thorogood).

Cape St. Vincent (site 4) $\left(37^{\circ} 02959\right.$ N, $008^{\circ} 98441 \mathrm{~W}$; elevation $65 \mathrm{~m}$ ) in 2007. Populations of C. hypocistis were sporadic at sites 3 and 4 ; hence these sites were not sampled as extensively as sites 1 and 2. Measurements were taken during the peak flowering season of C. hypocistis (mid March-mid April). The vegetation at each site consisted of coastal maquis dominated by Cistus spp. with a canopy of $50-100 \mathrm{~cm}$. Surveys were conducted at each site to assess the relative abundance of potential host species and the number of hosts infected with C. hypocistis. This parasite infects various members of the Cistaceae including both Cistus spp. and Halimium spp. [8], and given the paucity of literature on the host range of $C$. hypocistis, all members of the Cistaceae were considered to be potential hosts. A different assemblage of potential hosts grew at each site (see Table 1). At each site, an area of approximately $2500 \mathrm{~m}^{2}$ was sampled. Where accessibility was limited by vegetation, this area was divided into subplots of $100 \mathrm{~m}^{2}$. All Cistaceae were examined and the number of infected individuals was recorded. It was not always clear whether individual inflorescences represented separate plants; so hosts were scored for the presence or absence of $C$. hypocistis, and the number of inflorescences produced on each host was recorded to assess the density of infection. Where it was unclear which shrub was infected (root parasites may emerge at some distance from the host), the identity of the host was confirmed by excavating host-parasite connections. All excavations confirmed the visual observations.

\section{RESULTS AND DISCUSSION}

Cytinus hypocistis is a generalist holoparasite which can infect a range of species within the Cistaceae [8]. Here, we show that $C$. hypocistis does not use all potential hosts equally, and it is locally host-specific. C. hypocistis showed a clear pattern of host specificity and consistently infected $H$. halimifolium and C. monspeliensis where they occurred (see Table 1). Other species in the Cistaceae including Halimium calycinum, Cistus salvifolius, and Cistus crispus were not infected, even at sites where they were more abundant than $H$. halimifolium; therefore, C. hypocistis did not infect this host in proportion to its abundance at sites 1,3 , and 4 (see 


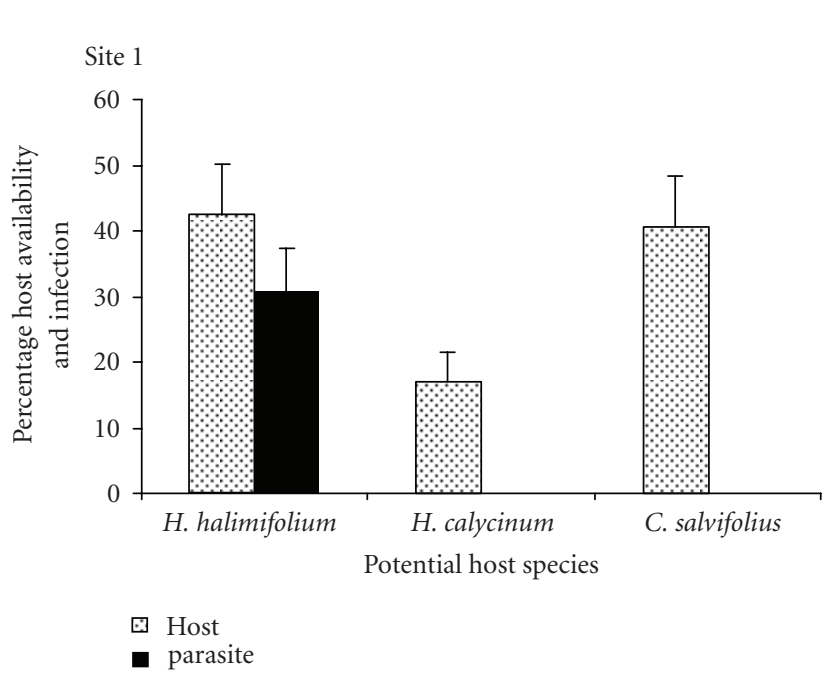

(a)



(c)

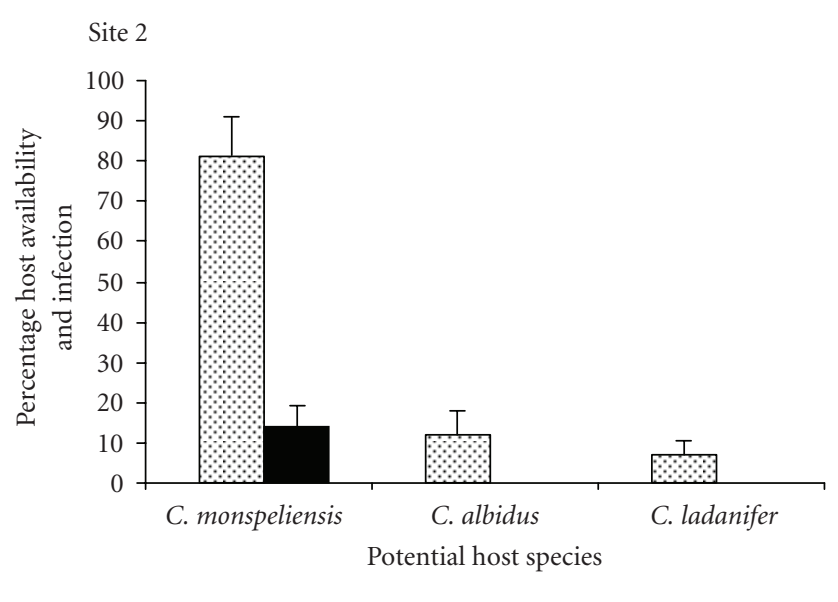

Host

- parasite

(b)

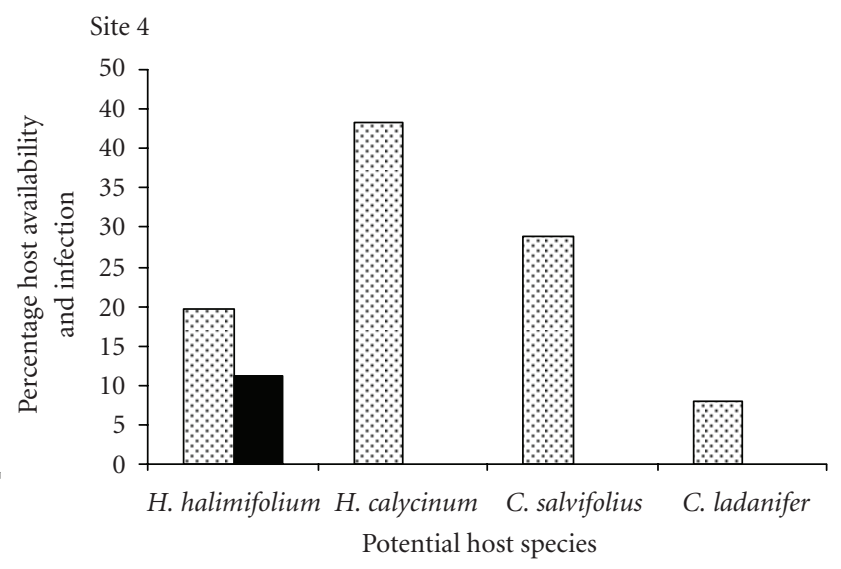

๑7 Host

- parasite

FIGURE 2: Host availability and infection of potential hosts at each site. Relative host availability is represented as the mean percentage of the total number of Cistaceae species present at each site. Parasite infection is represented as the mean percentage infection of the species of each host. Bars represent the standard error, included for sites sampled in two or more years.

Figure 2). At site 2, however, C. hypocistis infected C. monspeliensis which was the most abundant host species. Occasionally, C. hypocistis was also found growing on C. ladanifer at sites 2 and 4, though these individuals did not fall within the plots sampled. C. hypocistis was never encountered together with $H$. halimifolium and $C$. monspeliensis which may be due to the different ecological preferences of these hosts. While trends in host preference were consistent during the sampling period, infection levels varied annually, suggesting that the same parasites were not flowering each year (data not shown).

Over a period of six years, just three of the seven potential host species of Cistaceae were parasitized at four independent sites. Previous reports suggest that host species may appear to be preferred as an artefact of their abundance [3]. This was clearly not the case for C. hypocistis because the mean levels of infection were similar on $H$. halimifolium at sites 1 and 3, even though this host represented $42.4 \%$ of potential hosts at site 1 and just $3 \%$ at site 3 . Therefore, host abundance does not predict the prevalence of C. hypocistis. A similar pattern has been observed with the parasite Cuscuta costaricensis where $88 \%$ of parasite cover grew on only $54 \%$ of available host cover [2]. This may not apply as a general rule in parasitic plants, however, since host range in mistletoes (Loranthaceae) appears to shift with a change in the relative abundance of hosts [7]. Qasem [9] observed differences in the severity of infection of the hemiparasite Osyris alba on different hosts; host preference may be common to generalist parasites. Although a parasite may exploit multiple host resources, it may not necessarily obtain equal fitness from them [2]. Therefore, parasitic plants will discriminately infect hosts which enhance their growth and fitness [3].

C. hypocistis has been reported to be a perennial [10]; however, the annual fluctuation in parasite prevalence in 
our study suggests that this species may be either an annual, repeatedly infecting susceptible hosts, or a perennial which does not flower every year. In addition, infected host bushes were marked in 2004 and re-examined in 2005 but showed no sign of parasite regrowth (C. J. Thorogood and S. J. Hiscock unpublished data). Schneeweiss [11] suggests that the parasitic genera Orobanche and Phelipanche are generally host-specific perennials when growing on perennial hosts. A few species, however, are host-nonspecific annuals which parasitize annual hosts. Parasite specialization may therefore be associated with predictable resources (perennial hosts) and generalism with unpredictable resources (annual hosts). Thus, the reliability of host availability through space and time may determine patterns of host specificity [7].

The distinct ecological niches of $H$. halimifolium and $C$. monspeliensis could reinforce divergence of isolated races of C. hypocistis on these respective hosts. It would be interesting to compare infection levels at a site where both $\mathrm{H}$. halimifolium and C. monspeliensis co-occur with C. hypocistis, but we were unable to locate such a site. Such a site may not exist, since these species have distinct habitat preferences. Whereas Halimium spp. occur on sandy and siliceous soils, Cistus spp. often grow in dry scrub and open woodland [8]. Chloroplast DNA and nuclear DNA ITS sequences have revealed distinct host races in the hemiparasite Viscum album (Viscaceae). Reduced gene flow between such host races may result in genetic divergence [12]. Indeed, host specificity appears to have led to the genetic divergence and speciation of leaf beetles, Ophraella [13], and tephritid fruit flies [14]. It is possible that similar speciation events have occurred or that they are occurring in parasitic plants such as Cytinus. Four subspecies of $C$. hypocistis have been recognized in Europe, each with a distinct host range: subsp.hypocistis on various Cistus and Halimium spp.; subsp. macranthus on Halimium spp.; subsp. orientalis on C. parviflorus; subsp. pityusensis on C. clusii [8]. These subspecies appear to be distinct physiological races, which may be in the process of incipient speciation. Our data demonstrate that $C$. hypocistis also shows patterns of host specificity at a local level. We speculate that host-specific races of $C$. hypocistis may be isolated as a consequence of host niche divergence. This could be driving the allopatric speciation of this parasitic plant.

\section{ACKNOWLEDGMENT}

The authors would like to thank Katy Prentice and Owen Smith for their extensive contribution to the data collection carried out during this study.

\section{REFERENCES}

[1] J. G. Garcia-Franco and V. Rico-Gray, "Distribution and host specificity in the holoparasite Bdallophyton bambusarum (Rafflesiaceae) in a tropical deciduous forest in Veracruz, Mexico," Biotropica, vol. 28, no. 4, pp. 759-762, 1996.

[2] C. K. Kelly, D. L. Venable, and K. Zimmerer, "Host specialisation in Cuscuta costaricensis: an assessment of host use relative to host availability," Oikos, vol. 53, no. 3, pp. 315-320, 1988.
[3] M. C. Press and G. K. Phoenix, "Impacts of parasitic plants on natural communities," New Phytologist, vol. 166, no. 3, pp. 737-751, 2005.

[4] D. A. Norton and M. A. Carpenter, "Mistletoes as parasites: host specificity and speciation," Trends in Ecology and Evolution, vol. 13, no. 3, pp. 101-105, 1998.

[5] M. C. Press and J. D. Graves, Parasitic Plants, Chapman and Hall, London, UK, 1995.

[6] W. E. Seel and M. C. Press, "Effects of repeated parasitism by Rhinanthus minor on the growth and photosynthesis of a perennial grass, Poa alpina," New Phytologist, vol. 134, no. 3, pp. 495-502, 1996.

[7] D. A. Norton and P. J. De Lange, "Host specificity in parasitic mistletoes (Loranthaceae) in New Zealand," Functional Ecology, vol. 13, no. 4, pp. 552-559, 1999.

[8] T. G. Tutin, V. H. Heywood, N. A. Burges, et al., Eds., Flora Europaea, vol. 1-2, Cambridge University Press, Cambridge, UK, 2nd edition, 1993.

[9] J. R. Qasem, "Host range of the parasitic weed Osyris alba L. in Jordan," Weed Biology and Management, vol. 6, no. 2, pp. 74-78, 2006.

[10] J. A. López-Sáez, P. Catalán, and L. Sáez, Eds., Plantas Parásitas de la Península Ibérica e Islas Baleares, Mundi-Prensa, Madrid, Spain, 2002.

[11] G. M. Schneeweiss, "Correlated evolution of life history and host range in the nonphotosynthetic parasitic flowering plants Orobanche and Phelipanche (Orobanchaceae)," Journal of Evolutionary Biology, vol. 20, no. 2, pp. 471-478, 2007.

[12] D. Zuber and A. Widmer, "Genetic evidence for host specificity in the hemi-parasitic Viscum album L. (Viscaceae)," Molecular Ecology, vol. 9, no. 8, pp. 1069-1073, 2000.

[13] D. J. Funk, D. J. Futuyma, G. Orti, and A. Meyer, "A history of host associations and evolutionary diversification for ophraella (Coleoptera: Chrysomelidae): new evidence from mitochondrial DNA," Evolution, vol. 49, no. 5, pp. 1008-1017, 1995.

[14] D. Schwarz, B. M. Matta, N. L. Shakir-Botteri, and B. A. McPheron, "Host shift to an invasive plant triggers rapid animal hybrid speciation," Nature, vol. 436, no. 7050, pp. 546549, 2005. 

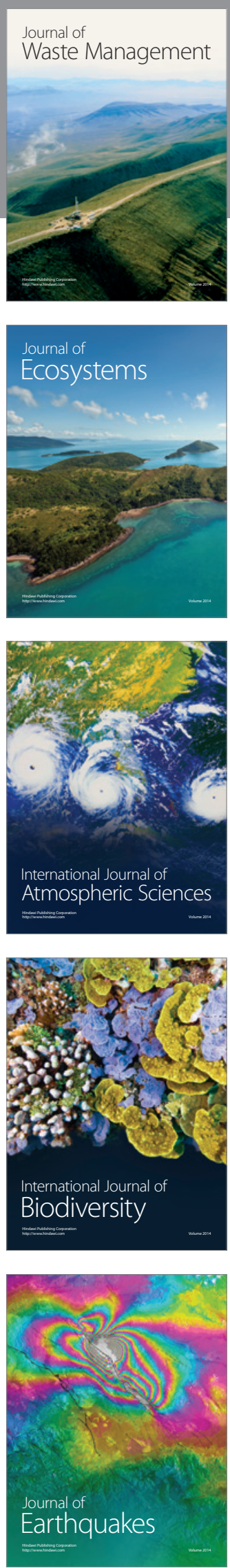
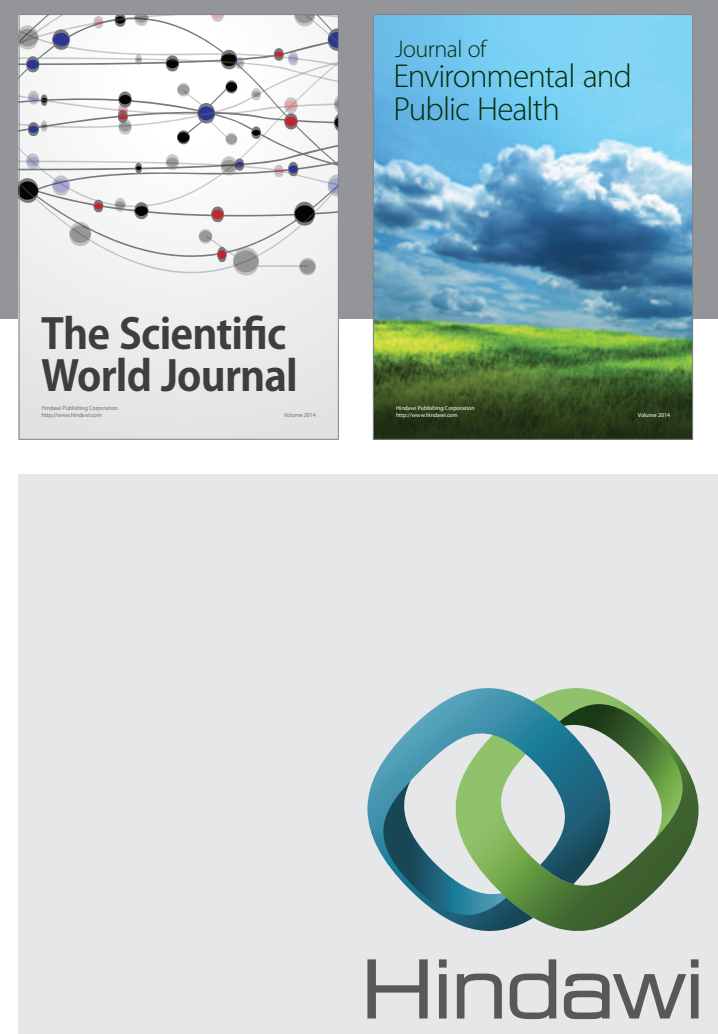

Submit your manuscripts at

http://www.hindawi.com
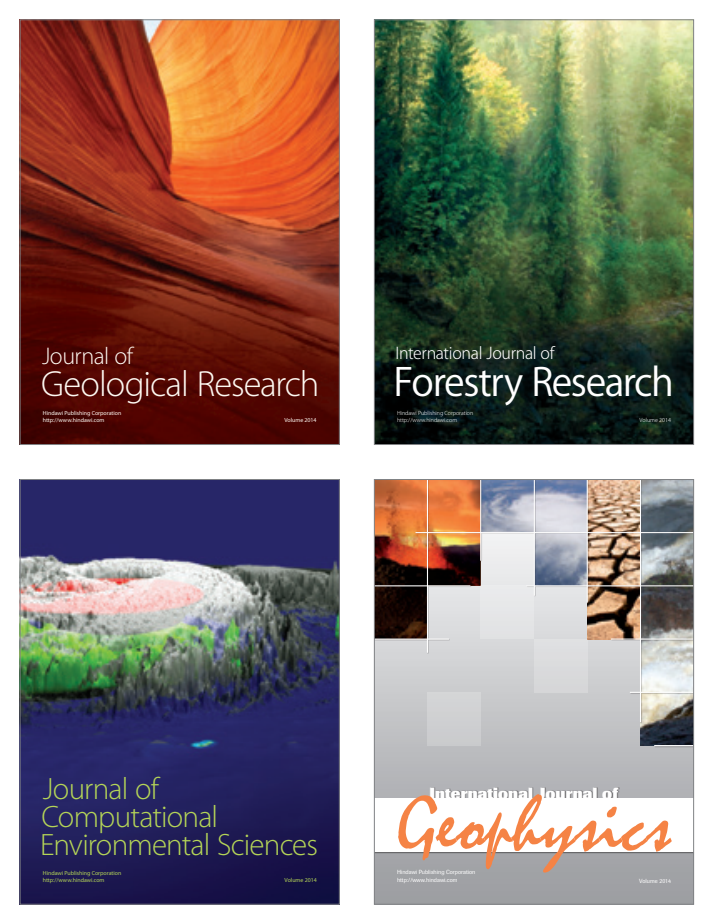
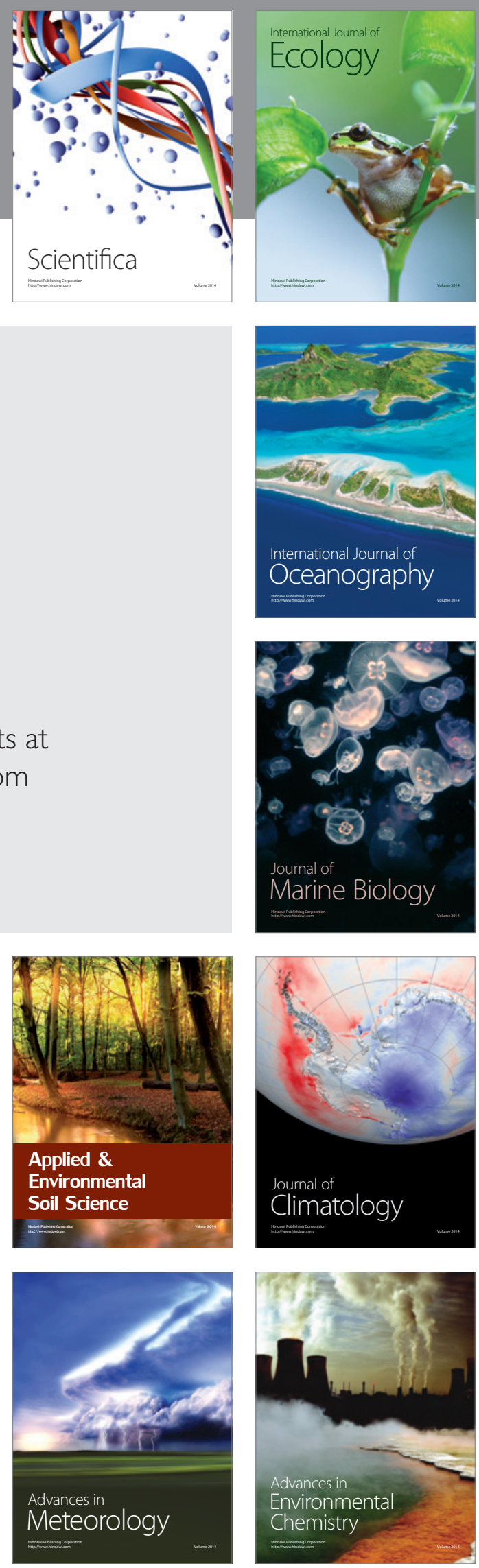